\title{
Urgency of the Right to Recognition for Identity's Belief as A Part of Human Rights
}

\section{Winda Wijayanti}

The Constitutional Court of the Republic of Indonesia.E-mail: stillbest_leo@yahoo.com

\begin{tabular}{l} 
ARTICLE INFO \\
\hline Keywords: \\
Belief; Believer; Human \\
Right; Identity; Right to \\
Recognition \\
How to cite: \\
Wijayanti, W. (2018). \\
Urgency of the Right to \\
Recognition for Identity's \\
Belief as A Part of Human \\
Rights, Hasanuddin Law \\
Review, 4(3): 296-314 \\
DOI: \\
10.20956/halrev.v4i3.1435 \\
\end{tabular}

\begin{abstract}
The right of recognition a belief is one of the basic human rights set forth in the Constitution. Population Administration Act as the executor of the constitutional mandate does not regulate of information column's "Belief" in an identity card (KTP-el) or a blank religion is a legal vacuum. Many debates occurred during the discussion and after the enactment of the Population Administration Act that only regulates the administration of population and issues between Religion and Belief as being very sensitive so that discussion of belief is considered not the domain of the Population Administration Act. Then, the absence of public participation in discussion of amendment Population Administration Act as a form of non-recognition of the existence of Believer in regulation. The problem is no rule for public participation in Population Administration Act. In fact, this paper used a normative juridical approach, with qualitative descriptive about debate of the Administration Population Act (DPR) to find out the urgency of the right to recognition for identity's Belief through KTP-el. The result showed that inclusion of information column's "Belief" is an entrance (gate) for the state's recognition of the people's belief and their constitutional rights attached to it. Not only through words, but the recognition of the state through the State Administrators is manifested by legislation and communication (dialogue) between state and its citizens to remove all the existing attributes with equally, parallel, and continuously.
\end{abstract}

Copyright ( 2018 HALREV. All rights reserved.

\section{Introduction}

Spiritual (includes mysticism, psychiatric, and spirituality) or Belief is formulated in 1950 is the source of the principle of the Godhead of the Almighty God to achieve Nobility or the perfection of life. ${ }^{1}$ Previously the term "Belief in God Almighty" is often referred to as "mainstream of belief". The term Belief is first known legally in Act Number 1/PNPS/1965 on Prevention of Misuse and/or Blasphemy. The term leads to

1 Rahmat Subagya. (1990). Kepercayaan, Kebatinan, Kerohanian, Kejiwaan, dan Agama. Yogyakarta: Kanisius, p. 70 . 
discriminatory treatment because of the word "stream" as meaning which gives negative meaning to its followers as heresy, atheism, communism, idolatry, and another pejorative stigma. The word "stream" itself has only been formally defined in the law, i.e. all schools or ideologies which may cause division or threaten the unity of the nation, among other beliefs that are contrary to the basic philosophy of the Republic of Indonesia. ${ }^{2}$

Definition of Belief in God Almighty is firmly stipulated in some provisions is the statement and the implementation of a personal relationship with God Almighty based on the beliefs embodied with the behavior of devotion and worship of God Almighty and the practice of virtue that his teachings derived from the local wisdom of Indonesian, whereas believer of belief formerly termed as "stream of indigenous belief's people", then defined as "Every person who acknowledge and believe values of appreciation of belief to God Almighty." according to Article 1 section 19 Government Regulation Number 37 Year 2007 about Implementation of Act Number 23 Year 2006 on Population Administration and Article 1 Section 3 of the Joint Regulation of the Minister of Home Affairs and the Minister of Culture and Tourism Number 43 Year 2009 and Number 41 Year 2009 on the Guidance of Service to Indigenous Belief's People to God Almighty.

Act Number 1/PNPS/1965 is discriminatory because of the oversight of the mainstream or the organization of the belief and the imposition of sanctions without legal protection for the people's belief. The inclusion of six religion embraced by the people of Indonesia includes Islam, Christianity, Catholicism, Hinduism, Buddhism and Khong $\mathrm{Cu}$ (Confucius) (Elucidation of Article 1 Act Number 1/Pnps/1965) as called "official religion". The government era's of President Soekarno, there was a legal that generated polemic up to now that is Act Number 5 Year 1969 on Statement of Various Stipulation of President and Regulation of President Act, finally becoming Act Number 1/PNPS/1965 through word "based on religion". The question of religion as the main and most important cause the relationship between the Believers to be not parallel to the Followers of religion cause negative meaning for the belief.

The purpose of Act Number 5 Year 1969 to prevent the misappropriation of religious teachings, to protect religious peace, to protect from religious defamation, to protect from the teachings not to embrace the religion of the One Supreme Almighty. Object of legal protection of Act Number 5 Year 1969 is Religion which has implication on a relation between Adherent Religion with Believer not as aligned as development partner in Fourth Paragraph of Preamble of the 1945 Constitution which read "... to protect all Indonesian nation and all of Indonesia blood spill ...". The purpose of this provision is to promote religion, to prevent abuse or blasphemy, and to secure the revolution and the provisions of society. The provision does not put forward the principle of Godhead is the most important thing for the people and the state of Indonesia which is the basis of the state as stated in Article 29 paragraph (1) of the 1945 Constitution related to the fact of diversity in Indonesia and mutual agreement to build Indonesia as stated in the Fourth Paragraph Preamble of the 1945 Constitution.

Indeed, Believer has the right to believe and to worship in a safe, comfortable, peaceful as well as those who are protected by Article 28E paragraph (2) the 1945 Constitution "Everyone has the right to freedom to believe in belief, and the attitude, in accordance with his conscience." Article 29 paragraph (1) the 1945 Constitution "State based on God Almighty", and Article 29 Paragraph (2) the 1945 Constitution "The State guarantees the independence of each people to embrace their respective faiths and to worship according to their religion and

2 See, Article 15 paragraph (1) Act Number 2 of 2002 about the Police of the Republic of Indonesia. 
belief.". Since the Second Amendment of the 1945 Constitution stipulated on 18 August 2000 constitutionally, the constitutional rights of the Believers in relation to the right to freedom of belief and the right to recognition of identity as Self-believers should be stronger through: 1) the right to recognition as a person in Article 28D paragraph (1) which reads "Everyone is entitled to the recognition, guarantee, protection and legal certainty of justice and equal treatment before the law."; 2) is recognized and protected by the Constitution to have the right to freely believe in belief as regulated in Article 28E paragraph (2) of the 1945 Constitution; 3) the right to the recognition as a person before the law as a human right that can not be reduced under any circumstance as provided for in Article 28I paragraph (1) of the 1945 Constitution which reads, "The right to life, the right not to be tortured, the right to freedom of mind and heart conscience, religious right, the right not to be enslaved, the right to be recognized as a person before the law, and the right not to be prosecuted on the basis of retroactive law is a human right which can not be reduced under any circumstances."; and 4) the obligation is subject to restrictions to guarantee the recognition of others in Article 28J Paragraph (2) of the 1945 Constitution which reads "In exercising their rights and freedoms, each person shall be subject to the restrictions laid down by law with the sole intent of guaranteeing recognition as well respect for the rights and freedoms of others and to fulfill fair demands according to moral judgment, religious values, security, and public order in a democratic society."

The existence of Article 64 Paragraph (1) of Act Number 23 Year 2006 concerning Population Administration amended by Act Number 24 Year 2013 regarding the Amendment of Act Number 23 Year 2006 regarding Population Administration as follows "ID cards include images of Garuda Pancasila symbol and map of the territory of the Republic of Indonesia, contains information about NIK, name, place of birth date, male or female, religion, marital status, blood type, address, occupation, nationality, photograph, validity period, place and date issued ID, signature of ID card holder, name and number of the parent officer who signed it." It does not include the column's Belief on ID card as a legal vacuum. Furthermore, Article 64 paragraph (5) Population Administration Act implicates the increasingly attached to stigma pejorative in positive law.

The absence of a confidential column on KTP set forth Article 64 paragraph (1) Act Number 23 Year 2006 raises a polemic up to KTP nor contains a Belief column for the Believer in Article 64 paragraph (1) Act Number 24 Year 2013. Whereas by nature, man as one of the creatures of God has the necessities of life and the recognition of identity that must be met and protected by the state through the constitution because of its nature as a dignity. The existence of discrimination against the Believer of legislation, among others: (1) the recognition of the identity of the population and religion imposed if neglected resulted in discrimination and negative label for the Believers (communist, atheist and perverted); ${ }^{3}$ (2) can not apply for a job as a state servant (Indonesia's National Army and National Policeman) because the requirement must be religion;4 (3) a civil servant candidate can not be taken oath or pledge according to his belief because in the Employment Act there is no recapitulation of oath for the believer of trust so that the consequences for his income and family allowance from work until retirement; 5 (3) marriage, birth, death, etc. can not be recorded by the Civil Note unless the Believer

3 Secretariat General of the House of Representatives of the Republic of Indonesia. (No Year). Proses Pembahasan Rancangan Undang-Undang Tentang Administrasi Kependudukan Buku 2. Jakarta: Secretariat General of the House of Representatives of the Republic of Indonesia, p. 656.

$4 \quad$ Ibid., p. 651.

$5 \quad$ Ibid., p. 669. 
embraces one of the Religions; ${ }^{6}(4)$ the rights of women and children's rights are not protected concerning the recording, birth certificates, education so as to be prone to violence and discrimination; ${ }^{7}$ (5) loss of joint property after divorce; 8 (6) place and procedure or burial ceremony; ${ }^{9}(8)$ there is no legal certainty regarding the official authorized to legalize the marriage so that the ratification through the court's appointment; 10 (9) performing rituals that do not match the teachings of parents/ancestors in schools due to the demands of religious education; 11 and (10) Believer are forced to be religious in order to obtain constitutional rights related to public services. ${ }^{12}$

KTP is the official identity of the population as a proof of self and access for the population of Indonesia for the acquisition of rights and the implementation of obligations containing some information about the population data is one of the documents of population so it is crucial to include also the column of Belief as a legal protection for the believer in the framework of the embodiment of one human rights that freedom believe in the belief in accordance with the conscience and created the balance of the position between religious adherents and belief-related beliefs of existence in society and law, worship and carry out important events in the life of the population ${ }^{13}$ with a sense of security, calm, and peace.

The placement of religion as something very high compared to other religions with the attitude of lack of respect and respect for other human beings who actually have the same dignity as another God's attainment causes the discussion of religion become over sensitive. When the difference appears to have reached its limit, the defense of religion as the honor of its followers becomes annoyed. Long debates about the inclusion of religious columns only because the belief is not a religion, ${ }^{14}$ the urgency of the inclusion of Belief, 15 and even does not include at all religious columns in KTP considered as discriminatory treatment and not useful 16 to appear in various forums in mass organizations, the Adherent of Religion and Believer, and government apparatus up to the discussion in the Working Meeting related to the Draft's of Population Administration Act (Draft's Adminduk Act) in the House of Representative (called $D P R) .{ }^{17}$ The implication of the inclusion of the confidence column in the ID card is

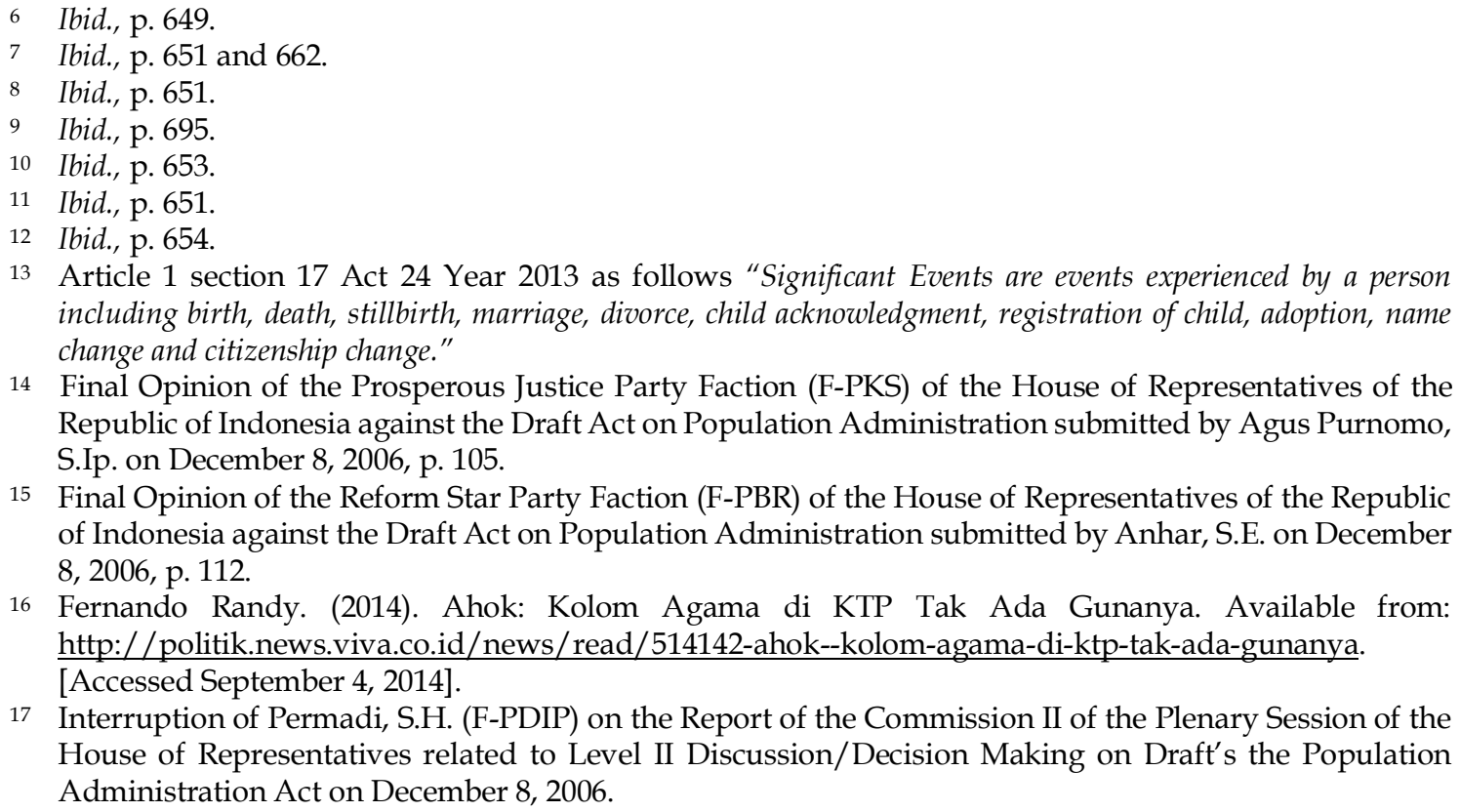

Article 1 section 17 Act 24 Year 2013 as follows "Significant Events are events experienced by a person including birth, death, stillbirth, marriage, divorce, child acknowledgment, registration of child, adoption, name change and citizenship change."

14 Final Opinion of the Prosperous Justice Party Faction (F-PKS) of the House of Representatives of the Republic of Indonesia against the Draft Act on Population Administration submitted by Agus Purnomo, S.Ip. on December 8, 2006, p. 105.

15 Final Opinion of the Reform Star Party Faction (F-PBR) of the House of Representatives of the Republic of Indonesia against the Draft Act on Population Administration submitted by Anhar, S.E. on December 8, 2006, p. 112.

16 Fernando Randy. (2014). Ahok: Kolom Agama di KTP Tak Ada Gunanya. Available from: http://politik.news.viva.co.id/news/read/514142-ahok--kolom-agama-di-ktp-tak-ada-gunanya. [Accessed September 4, 2014].

17 Interruption of Permadi, S.H. (F-PDIP) on the Report of the Commission II of the Plenary Session of the House of Representatives related to Level II Discussion/Decision Making on Draft's the Population Administration Act on December 8, 2006. 
significant, especially for women of Believer and their generation. The inclusion of the KTP column's Belief in the KTP is regarded as very sensitive ${ }^{18}$ and serious considering the history and facts of the diversity of religions and beliefs in Indonesia so that the Government and the House's fraction views Religion and Belief is a very sensitive issue and the stream of Belief will not develop into recognition. ${ }^{19}$

The Racial Anti-Discrimination Committee (CERD) on August 152007 recommended to the Government of the Republic of Indonesia through its CERD/C/IDN/CO/3 Letter to remove religious columns in KTP which are deemed to have caused discriminatory acts, especially against Belief groups. ${ }^{20}$ Indonesia is perceived as failing to protect, fulfill, and guarantee the rights of Believer in the inclusion of the Belief column which is the recognition of one's identity. For example, in countries where there are ethnic, religious or linguistic minorities, persons belonging to such minorities should not be denied the right in community with members of their other groups, to enjoy their own culture to embrace and practice their own religion or use own language.

Based on the research conducted by the National Commission on Violence Against Women, 65 cases in various aspects of human life, such as 34 cases of neglect in the duty of population, 9 cases of discrimination in access to the right to work and the benefits of the work, 8 cases in access to education, 3 cases of obstacles in access to government assistance, 3 cases of obstacles in access to the funeral, 2 cases of obstacles in the construction of houses of worship, 5 cases of obstacles in worship, and 1 back case organize confidence. ${ }^{21}$ The main of problem is a blank religion column's on ID Card that is regulated in Population Administration Act cause sustained pejorative stigma and discrimination for Believer. Population Administration Act does not set information column about Belief on ID card and the urgent's right to recognition for identity as a part of human rights.

The issue of the Believer continues, when the Admendment's Adminduk Act did not involve the Believer to the Draft Act's discussion. Based on the history, Draft Amendment of Adminduk Act did not require a long time to an act, because of efficiency. ${ }^{22}$ The Draft's Adminduk Act also does not regulate public participation as a necessity in drafting. Human rights of the Believer cannot be protected causing injustice, so some Believers submit a petition to the Constitutional Court of Indonesia for judicial review related to the absence of a column's Belief in KTP on September, 28 2016.23

18 Secretariat General of the House of Representatives of the Republic of Indonesia. (No Year). Proses Pembahasan Rancangan Undang-Undang Tentang Administrasi Kependudukan Buku 2. Jakarta: Secretariat General of the House of Representatives of the Republic of Indonesia, p. 223.

19 Ibid., p. 231.

20 Trisno S. Susanto, etc. (2011).Kertas Posisi: Menuntut Pemenuhan Hak-hak Konstitusional Penghayat Kepercayaan Terhadap Tuhan Yang Maha Esa. Jakarta: Human Rights Working Group, p. ix.

21 Andy Yentriyani, etc. (2016). Laporan Hasil Pemantauan tentang Diskriminasi dan Kekerasan Terhadap Perempuan Dalam Konteks Kebebasan Beragama dan Berkeyakinan Bagi Kelompok Penghayat Kepercayaan/Penganut Agama Leluhur dan Pelaksana Ritual Adat. Jakarta: Komisi Nasional Anti Kekerasan Terhadap Perempuan, p. 6.

22 Official Message on plenary meeting of DPR 2013-2014 conference time II closing to 12, November 26, 2013, p. 23.

23 Randy Ferdi Firdaus. (2013). Ketua MPR: Syiah, Sunni, Ahmadiyah Saya Terima di Sini. Available from: http://m.merdeka.com/peristiwa/ketua-mpr-syiah-sunni-ahmadiyah-saya-terima-di-sini.html. [Accesed December, 21 20018]. 


\section{Method}

This research is a normative legal research that is legal research that puts law as a building of norm system among others are principles, norms, rules of legislation, court decision, agreement, and doctrine ${ }^{24}$ to answer the legal problems faced and produce arguments, theories or new concepts as prescriptions in solving the problems encountered. ${ }^{25}$ Normative legal research refers to positive law within the national legislation namely the 1945 Constitution and the Population Administration Act. This paper uses this descriptive qualitative analysis, namely the decomposition of the data obtained in a systematic description based on human rights of theory, the theory of justice, and the theory of democration deliberative.

\section{Population Administration Act Does Not Set Information Column's "Belief" in the KTP}

The discrimination as result the absence of the column's Belief as a form of state injustice in the preparation of legislation. Gustav Radbruch argued in law the need for elements of legal certainty, justice, and utility. ${ }^{26}$ Based on Draft Population Administration Act dialogue, only the PDI-P faction considers that the Adminduk Act is still discriminatory and has not fulfilled the justice of the community so that the PDI-P faction does not follow the decision-making process. ${ }^{27}$ There are many factions of the House of Representatives who declare that there is no discrimination in the Act Adminduk and recognize the diversity in Indonesia but which supports the column's Belief is only one (faction) ie the PDI-P faction. Discussion of Belief is the appropriate forum for harmonizing and bridging with existing laws ${ }^{28}$ and regulations and future legislation as important events in the life of Believers will be arranged in the Draft's Adminduk Act covering births, marriages, and death that originated and sourced from the recognition of identity through ID card. In principle, a person must be known before his existence and then others know the person to be considered existed and recognized by others.

The government at the time argued that the issue of Belief can not be included in the Adminduk Act but a special political regime with the domain of the Department of Religious Affairs through other laws. ${ }^{29}$ Unfortunately, Belief who gave testimony in public hearing of Draft's Adminduk Act is said to be victims of politicization. ${ }^{30}$ Andi Yuliani Paris (F-PAN) stated information from the Director General of Adminduk that Indonesia has not had the previous population database so that the data in the form of the number of people who live Belief and the amount of Belief can not inventory well

24 Mukti Fajar ND and Yulianto Achmad. (2007). Buku Ajar: Dualisme Penelitian Hukum. Yogyakarta: Pensil Komunika, p. 25.

25 Peter Mahmud Marzuki. (2005). Penelitian Hukum. Surabaya: Kencana, p. 35.

26 Sudarsono. (2007). Kamus Hukum Edisi Baru, Jakarta: Rineka Cipta, p. 397.

27 Secretariat General of the House of Representatives of the Republic of Indonesia. (No Year). Proses Pembahasan Rancangan Undang-Undang Tentang Administrasi Kependudukan Buku 1. Jakarta: Secretariat General of the House of Representatives of the Republic of Indonesia, p. 145.

28 Secretariat General of the House of Representatives of the Republic of Indonesia. (No Year). Proses Pembahasan Rancangan Undang-Undang Tentang Administrasi Kependudukan Buku 2. Jakarta: Secretariat General of the House of Representatives of the Republic of Indonesia, p. 557.

29 Secretariat General of the House of Representatives of the Republic of Indonesia. (No Year). Proses Pembahasan Rancangan Undang-Undang Tentang Administrasi Kependudukan Buku 3. Jakarta: Secretariat General of the House of Representatives of the Republic of Indonesia, p. 34-35.

$30 \quad$ Ibid., p. 714. 
until now. ${ }^{31}$ When the column's Religion state" - " or " " (Blank religion column) on ID card, the population database can not follow the dynamics of the development Belief of data inventory because there are Beliefs that appears and disappears.

Based on the Monograph of the Discussion Process on the Draft's Adminduk Act regarding the inclusion of the Religion column and the Confidence column in the KTP can be concluded. First, the inclusion of column's Religion and Belief on KTP involves citizens' basic rights in the important events of human life including the right to recognition connected to person's identity, the right to the registration of marriage, the right to the birth of the child, the right to work, and the right to a death ceremony feasible. Second, the factions in DPR all agree to the inclusion of the Religion column, but there are 4 (four) fractions which expressly reject the column Belief on KTP are F-PPP, FPKS, F-PAN, and F-PG ${ }^{32}$ that are inclusive and not comprehensive thinking (universal). Only one fraction supports Belief column is F-PDIP. In the end, the filling of the Religion column in the legislation was agreed by 27 people from 50 people and 10 fractions from 10 factions not to be filled but recorded in the population database. ${ }^{33}$

Eddy Mihati from the Faction of Indonesian Democratic Party of Struggle (F-PDIP) from Draft Adminduk Act until the changes insisted to fight for the inclusion of the column's Belief on KTP to accommodate the belief in God Almighty as protected in the constitution. ${ }^{34}$ Believer call for the confession of Belief because they exist, believe, and recognize the one God, the Almighty God. The proposal for the inclusion of religious columns in the KTP had a long debate, a matter that was considered very sensitive, a minority vote of Belief lost in the majority of Religion in the discussion of the Adminduk Act resulted in a majority vote agreement to include the column of religion on ID card.

PDI-P faction through Arif Wibowo (Vice Chairman of Commission II) proposed the abolition of Religion column on KTP to avoid discrimination in areas where the population has a certain religious majority, but the proposal was not continued until the final discussion due to the constraints of population data recording must include religion. ${ }^{35}$ The inclusion of the column's Belief as one of the state's recognition of the existing Belief in Indonesia and the protection of citizens identity, ${ }^{36}$ so that PDI-P Faction proposes a change regarding the inclusion of the column's Religion/Belief 37 and fight for protection citizen of their believe. ${ }^{38}$

Based on the Minutes of Working Committee Meetings, the debate has always been about the state's recognition of Religion and the terms "official religion", "unofficial religion", discrimination for Belief, there are two interpretations of Article 29 paragraph (2) the 1945 Constitution which raises the debate and opinion outside the six religions is not a religion but Belief, religion's topic as a very sensitive area. The implication of that affects the paradigm of some parties in viewing Religion and Belief in Indonesia. There

31 Secretariat General of the House of Representatives of the Republic of Indonesia. (No Year). Proses Pembahasan Rancangan Undang-Undang Tentang Administrasi Kependudukan Buku 2. Jakarta: Secretariat General of the House of Representatives of the Republic of Indonesia, p. 547 and 552.

32 Ibid., p. 227 and 228.

33 Ibid., p. 642 and 752.

34 Monograph of the Working Committee Meeting of the Draft Amendment to Act Number 23 Year 2006 about Population Administration (Division of Home Affairs, Regional Autonomy, State Apparatus and Bureaucratic Reform, Elections, Land and Agrarian Reform) 2012-2013 Period IV Trial Period on June 29, 2013, p. 56.

$35 \quad$ Ibid., p. 56.

36 Ibid., p. 63.

$37 \quad$ Ibid., p. 56 and 58.

$38 \quad$ Ibid., p. 58. 
is a sense in the House of Representatives that Indigenous Belief's People are protected by the state as long as they remain firm in their beliefs to perform their rituals without relating to the state-approved religion. ${ }^{39}$

Golkar Party Faction (F-PG), M. Basri Sidehabi, argues against comparison with United States and Japan that the issue of belief and religion is very sensitive. Religion as a very sensitive matter, there is no agreement regarding the Religion/Belief column between PDI-P faction and other factions which resulted in the delayed discussion to discuss other issues. ${ }^{40}$ Population Administration is background of the column's Belief can not be included in the KTP because of: 1) KTP is a matter of population administration not a debate related to the belief of the population; 2) there has been an earlier commitment related to the interpretation of "belief" in Article 29 paragraph (2) of the 1945 Constitution which refers to Religion; and 3) the population of Indonesia is the majority of religions while the inclusion of religious columns as information about the identity of the population regarding religious ordinances, such as the burial of the corpse, marriage, and others. Responding to several sessions of discussion in the DPR regarding legal vacuum in the inclusion of the column of Belief on ID card that: 1) the inclusion of the column of trust as the acquisition of human rights on the recognition of the identity of the Believers in the same relation with the followers of the religion before the law as an irrevocable human rights (non derogable rights), which is the entrance to the acquisition of the rights to important events in human life and civil rights; 2 ) the constitutional losses of Believers are still many because there is still a lawsuit to examine the Adminduk Law related to the inclusion column's of Belief in KTP and Card Family (called KK); 3) can not be denied diversity (pluralist) in the Indonesian nation so that legislator must also look at different paradigms (inclusive and comprehensive) through humanity that is mutual respect. Such diversity must be protected and respected as an inherent and inwardly Indonesian personality.

\section{The Urgent's Right of Recognition to Belief for Identity as A Part of Human Rights}

Recognition of the existence of Belief has been only a speech without any real action (realization) and legal protection through legislation. ID cards that only include columns of Religion without listing the column's Belief (blank religion column) as a legal vacuum of the Adminduk Act implies the abolition of the rights of the Believer that they do not feel the security, comfort, and peace in living and worshiping according to their beliefs and carrying out important events in their life properly, safe, and peaceful.

Recognition of identity is the most basic human right as a non derogable rights or entrance to the recognition of other human rights. Basically man can not live alone. When one lives with another human being, the person needs recognition of himself (name, nature, way of life, way of thinking) as a sign when one is appreciated by another human being. The acknowledgment of a person to others as the abolition of discrimination implies an unlawful, natural and unlawful treatment resulting in a violation of human rights. Discrimination occurs when a person is not recognized because of human differences on the basis of religion, ethnicity, race, ethnicity, group, class, social status, economic status, gender, language, political beliefs so that his or her human rights can be reduced, disregarded or deleted in politics , economic, legal, social, cultural, and other aspects of life as regulated in Article 1 paragraph 3 Act Number 39 
Year 1999 regarding Human Right. The right to be recognized as a person that can not be reduced based on human rights under Article 4 Act Number 39 Year 1999. The existence of a person can be known through identity as person or person is one of the basic rights which can not be reduced.

The right and freedom of religion and belief is one of the essential human rights as a manifestation of the ultimate human rights. It is often said, therefore, that religious rights and freedoms are a non-derogable rights human rights that can not be reduced under any circumstances. ${ }^{41}$ As Ifdhal Kasim and Laica Marzuki, states parties may undertake to undermine or compromise the obligation to fulfill non-derogable rights, whereas nonderogable is not permitted. Article 9 paragraph (2) European Convention on Human Rights (ECHR) requires that restrictions be well defined by the law and necessary in a society's democracy. First, the determining regulation must be accessible and citizens should be able to have such access. Secondly, the law should be formulated appropriately to enable citizens to manage their behavior fairly. ${ }^{42}$ Ifdhal Kasim said that non-derogable rights are absolute rights and should not be diminished by the state party, even in an emergency. ${ }^{43}$ Based on the justice, maqhasid al-Syariah theory proposed by Asy-Syatibi which is the main proposition in the discussion of human rights that the Shari'ah aims to realize the maslahah for people in the world and the hereafter. ${ }^{44}$ Maqasid al-syariah centered on maslahah (the goals of Islamic Shariah) that must exist to manifest life ${ }^{45}$ that is Hifdz al-nafs (protection of the soul, the right of individual life) 46 is a protection of human rights. Human rights are essential for every human being because man is created universally by God to have unlimited soul, spiritual, other people even by the state though (non derogable rights). ${ }^{47}$ Thus, it is said justice when a state regulated about protection Belief in God Almighty as one of human rights. It can not be reduced or inviolable as protection for man itself related to the meaning of its creation to the world and its relation between that man and his Creator and his fellowmen.

Believers as a group of people who have a weak and limited position included in affirmative action. Affirmative action is a policy, temporary special treatment is stipulated in legal legislation to equalize the level of development of certain groups that have experienced discrimination with other groups in the community. ${ }^{48}$ Affirmative action as a policy that is temporary in nature, so that the right to recognition of the Believer's Rights which is part of human rights cannot be applied temporarily but continuously because human rights are related to the identity and existence of someone in society that must be recognized as giving from God who created human.

41 Tore Lindholm, etc. (2010). Kebebasan Beragama atau Berkeyakinan: Sejauh Mana? Sebuah Referensi tentang Prinsip-Prinsip dan Praktik. Yogyakarta: Kanisius, p. 203 on Yusdani. (2011). "Kebebasan Beragama Perspektif Hak Asasi Manusia". Al-Mawarid, XI (2), September-January: 273.

42 Foreign and Commonwealth Office. Freedom of Religion or Belief Toolkit: How the FCO can Help Promote and Protect This Human Right. Available from: https://www.gov.uk/government/uploads/system/ uploads/attachment_data/file/561516/Freedom_of_Religion_or_Belief_Toolkit_-_2016.pdf. [Accesed January 23, 2017].

43 Ifdhal Kasim. (2000). "Konvensi Hak Sipil dan Politik, Sebuah Pengantar”. Jurnal Analisis CSIS, XXIX (4): 413-416.

44 Asy-Syâtibi, Al-Mufâqât fi Usul al-Syarî'ah, Book I, Second Juz, p. 4 on Parluhutan Siregar. (2014). “Etika Politik Global: Isu Hak-hak Asasi Manusia”. Jurnal Penelitian Medan Agama, 6 (1): 11.

45 Ibid.

46 Asy-Syatibi, Op.Cit., p. 8 on Siregar, Ibid.

47 Ibid.

48 Aep Gunarsa, (Ed.) (2011). Butir-butir Pemikiran Dalam Hukum: Memperingati 70 Tahun Prof. Dr. B. Arief Sidharta, SH.. Bandung: PT. Refika Aditama, p. 116 and 118. 
According to Hannah Arendt who follow the thinking TH Green and Hegel regarding the right to recognition as 'the right to have rights' that without the right to recognition a human being has no stateless identity and rightless. ${ }^{49}$ According to Arendt, recognition appears in conversation or dialogue (communication), speech, and action in a community. Recognition is expressed in a community. Every human has a right wherever that existence of human being. Recognition as fundamental, when humans know each other and communicate is a right to recognition ${ }^{50}$ and a reward of a human and his community towards other human beings related to his existence as a whole in a community. Arendt also argued that the most important right is to have basic rights. God created man as dignity. ${ }^{51}$ Naturally, humans as social beings who have to interact (to communicate) so that every human must know and respect each other.

Related to the right of recognition, Article 28D paragraph (1) the 1945 Constitution says "Everyone has the right to the recognition, guarantee, protection, and fair legal certainty and equal treatment before the law." The identity number of a resident is unique or unique, single, and attached to a person who is registered as an Indonesian resident contained in the definition of the Population Identification Number (NIK) as stipulated in (Article 1 Sub Article 12 Act Number 23 Year 2006) is a unique identity number or unique, singular, and attached to a person who is registered as an Indonesian resident. So, all data elements of the population on ID card is unique or unique, single, and attached to someone who is registered as a resident of Indonesia. Column's religion as one of the element data of population, so the data about Religion in KTP also apply unique character, single, and attached to someone. Inclusion Religion columns only on KTP as state discrimination to Indonesian citizens who have confidence in God Almighty beyond the Religion which is officially recognized by the state.

The inclusion of the column's Belief is also unique, singular, and attached to the Indigenous Belief's People, as well as the Religion column. Based on the unique or unique, singular, and attached properties, the data of the population elements such as the inclusion of the column's Religion/Belief is the official identity and the self-proof (identity) that can not be separated and separated by anyone as a belief of a person to God Almighty as guaranteed and protected by Article 29 Paragraph (1) the 1945 Constitution (Article 1 Sub Article 14 of Act Number 23 Year 2006) to obtain fair recognition, guarantee, protection and legal certainty and equal treatment before the law. Therefore, the right to the recognition of one's identity or identity through belief in God Almighty in the constitution is the uniqueness and respect of a very high state of one's existence as a dignified human being which is not owned by the constitution of other countries such as Malaysia and Turkey.

Based on International Development Law Organization (IDLO) Year 2013 data, there are nine countries that include religious columns in identity cards such as Afghanistan, Egypt, Indonesia, Jordan, Myanmar, Pakistan, Turkey, Saudi Arabia and Syrian Arab Republic. ${ }^{2}$ According to the United Nations (UN), the inclusion of religious columns in identity cards is that the classification of religion may lead to intolerance, negative

49 psa, Recognising Recognition: Hannah Arendt on (the Right to Have) Rights. Available from: https://www.psa.ac.uk/sites/default/files/988_509.pdf. [Accesed January 16, 2018].

50 Ibid.

51 psa, Recognising Recognition: Hannah Arendt on (the Right to Have) Rights. Available from: https://www.psa.ac.uk/sites/default/files/988_509.pdf. [Accesed January 16, 2018].

52 International Development Law Organization (IDLO). (No Year). Freedom of Religion or Belief and The Law: Current Dillemas and Lessons Learned. New York: International Development Law Organization (IDLO), p. 30. 
stigma, discrimination, incitement and violence against a person based on his or her religion or belief from the target of an organization or group of people who are extremely extreme to their religion or belief, when there is an omission from the state. ${ }^{3}$ In the United States, Britain, Canada and Australia there is a debate on identity cards and registration systems as state control and touches the privacy of its citizens. ${ }^{54}$ For example, Australia only includes information that minimizes people's reaction to sensitive data. 55

In contrast to its practice in Indonesia, religious columns are very important as religious identities because most (majority) Indonesians are religious residents consisting of various religions and beliefs and constitutions applying the principle that the state of Indonesia is based on the One Supreme God. Basically, each country may determine the policy of the religious column on its identity card as a mark of the religion or belief of its citizen through identity cards, passports or other official documents, provided that the country implements equal treatment or non-discrimination principle for every citizen. ${ }^{56}$

Malaysia Government in September 2001 officially issued a multifunctional smart identity card for its citizens named MyKad. ${ }^{77}$ Malaysia successfully implemented single identity number (SIN) as a smart card with multiple benefits in one card in the field of public service for government, community, and businessman 58 who prioritizes protection of personal information covering all personal information from different sources owned by someone. ${ }^{59} \mathrm{MyKad}$ has technological advancements in the Population data element or the Religion column is not an acknowledgment of Malaysian citizens identity or identity, because MyKad is more of a multifunctional smart card. In addition, the Constitution of the Federation of Malaysia does not regulate the right of recognition and right of religion and trust as non derogable right.

There is the opinion of a philosopher named Protagoras that in a democratic country, the role of citizens in formulating laws is so great that the citizens themselves determine the content of the law. According to him no objective or human truth is the size of everything (pantoon khrematoon metron anthropos) to determine good and fair. ${ }^{60}$ People who know about the struggle in life, its development and its practice from the history of its life, so based on these two things should every human being should respect the rights and freedoms of other human beings. Furthermore Socrates argues that human knowledge will bring man to good and right. ${ }^{61}$ Related to justice occurs when a person

53 Ibid.

54 Jim Fussel. (2001).Group Classification on National ID Cards as a Factor in Genocide and Ethnic Cleansing,A paper presented on November 15, 2001 to the Seminar Series of The Yale University Genocide Studies Program.

55 Mathews Thomas. (2004).“Is Malaysia's MyKad The 'One Card To Rule Them All' ? The Urgent Need To Develop A Proper Legal Framework For The Protection of Personal Information In Malaysia". Melbourne University Law Review, Volume 28: 487.

56 International Development Law Organization (IDLO). (No Year). Freedom of Religion or Belief and The Law: Current Dillemas and Lessons Learned. New York: International Development Law Organization (IDLO), p. 35.

57 Mathews Thomas. (2004). “Malaysia's MyKad The ‘One Card To Rule Them All’? The Urgent Need To Develop A Proper Legal Framework For The Protection Of Personal Information In Malaysia”. Melbourne University Law Review, 28: 474.

58 Dimas Dwi. (2017). Membandingkan e-KTP Ala Indonesia dengan MyKad Punya Malaysia. Available from: https://semarak.news/2017/03/14/11689-membandingkan-e-ktp-ala-indonesia-mykad-punyamalaysia.html. [Accessed October 9, 2017].

59 Thomas, Op.Cit., p. 474 dan 484.

60 Theo Huijbers. (2006). Filsafat Hukum Dalam Lintasan Sejarah. Yogyakarta: Pustaka Filsafat, p. 21.

61 Ibid. 
obeys the principle of relationship to fellow human beings that do not harm a person (neminem laedere) and give to each person what is his right (unicuique suum tribuere). ${ }^{62}$

According to Supardi Suparlan, an inherent identity is acquired through action; life history; the recognition or acknowledgment of a person belonging to a group based on a series of characteristics which constitute a unified whole, and marking it so that it can be included in that group. ${ }^{63}$ Identity is also defined as a hallmark, sign or identity, personality. ${ }^{64}$ As Aristotle argues, human beings as social beings must be social when living in society that man becomes whole when living in a union (only in a social union is the individual complete). ${ }^{65}$ According to John Rawls on the good life of society that good society will produce good members of society in which there is the personal good that everyone has as a person including strong intelligence, energy, determination, 66 and sincerity. Furthermore, goodness can be obtained from wise members of society, because its wisdom will make a rational plan for its life. ${ }^{67}$ Good people will do good things and produce something well too, because anything done with sincerity will produce something good. Injustice occurs when there is a distinction between race, religion, skin, and so forth, resulting in the development of life based on existing differences between race, religion, or class as something that is not good. ${ }^{68}$

Gnooti Seauton means recognizing yourself that reflecting on legislation will lead to a reflection of the reasons for the issuance of legal policy, the implications in society and the legal system, and solutions. The task of the state according to Socrates is the education of citizens in the primacy (arete). ${ }^{69}$ Reflection is that someone thinks of different people but they exist and are equal, so that their existence and rights should be respected and respected to sit parallel to discuss issues inclusively rather than exclusively on the basis of egoism over Religion comprehensively. The gift of God should man use wisely for other human beings. A human is given a unique, different identity, and freedom from God Almighty, should recognize other human beings and give freedom to another. Sensitivity may occur in other countries, but it should not happen in Indonesia because Indonesia has the principles and reality of Bhinneka Tunggal Ika (Unity in Diversity) that must be upheld and continue.

Follow Arendt's $\mathrm{s}^{70}$ thoughts about one's acknowledgment of others through conversation or dialogue (communication), speech, and action in a community. In harmony with that thought, recognition can be known by the measure of three ways people express their attitudes inclusively or exclusively include: a. communication and speech sincerely that the disclosure of opinions may differ from another, but does not attempt to influence the public (provoke) so that others may be influenced or follow their will and not impact, degrade, and reduce thoughts and beliefs of others, and invite someone to return to a

$62 \quad$ Ibid., p. 33.

63 Parsudi Suparlan. (1999). Universitas Mercu Buana. Modul Perkuliahan Pendidikan Kewarganegaraan Pokok Bahasan Identitas Nasional. Available for: http://studylibid.com/doc/27027/a.-pengertian-identitasnasional. [Accessed January 8, 2018].

64 Asykuri Ibn Chamim, etc. (2003). Civic Hukum: Pendidikan Kewarganegaraan. Yogyakarta: Diktilitbang PP Muhammadiyah dan LP3 UMY, p. 209 on Husamah. (2009). “Mengusung Kembali Khazanah Identitas Budaya Bangsa". Jurnal Bestari, 42, p. 36.

65 Huijbers, Op.Cit., p. 197

66 Ibid., p. 194.

67 Ibid.

68 Ibid., p. 195-196.

69 Ibid., p. 22.

70 psa, Recognising Recognition: Hannah Arendt on (the Right to Have) Rights. Available from: https://www.psa.ac.uk/sites/default/files/988_509.pdf. [Accesed January 16, 2018]. 
particular Religion. To worship according to his religion and according to his belief. It means the way we face or pray or praise God who created man and the universe. The way every human can be different. It is open but restricted but not interfere with another. Thus, the principle of legal protection for Believer is the recognition of its existence, the recognition of diversity as a unified nation, having equal rights with Believer, and the partnership of spiritual development to live in harmony. (Decree of Peoples Consultative Assembly Number IV/MPR/1973); and b. action through several stages, among others. 1) realizing and acknowledging his position in the heart (the deepest subconscious) and the problems around him sincerely by resisting egoism (exclusivity); 2) compare legislation to view the history (problem) and facts in the community regarding the legal vacuum and discrimination against certain people or groups; 3 ) find solutions through existing fact-based review activities and current and prevailing laws and regulations; and 4) carry out active and tangible actions to objectively define the outcome of his review. The act of the State Organizer is sincerely to take the best course without discrimination, to take innovative steps, its actions can unify the differences, and continue to fight for human rights.

Decision of Indonesia Constitutional Court Number 97/PUU-XIV/2016 revokes Article 61 paragraph (1) and Article 64 paragraph (1) the Adminduk Act because it is contradictory to Article 28D paragraph (1) the 1945 Constitution and has no conditional binding legal force insofar as it does not include "Belief". In the future, inclusion of the element demographic data on religion for Believer only by listing the concerned as "Belief" without detailing variety of Belief on KTP to realize the orderly administration of population and the number of Belief in Indonesia's society are substantial and diverse. ${ }^{71}$ The implication that recognition of state on Belief not only in the field of population administration but all regulations on the basis of among others. First, the right or freedom of religion (including Belief in God Almighty) is the inherent right of everyone because it is derived from natural rights, not the gift of the state. These rights are contained in the Constitution so that the state has a constitutional obligation to protect and be responsible for ensuring that citizens enjoy their rights in practice or in everyday reality..$^{72}$ Second, the term "religion" in Article 61 paragraph (1) and Article 64 paragraph (1) Adminduk Act as "religion recognized as religion in accordance with the provisions of the Act" leads to the absence of recognition, guarantee, protection and legal certainty fair and equal treatment before the law for the Citizen of Believers so that the term "religion" includes Belief. 73 Thus, term "religion" in legislation not only covers Religion but also Belief in God Almighty does not only apply to Adminduk Act but all applicable laws (ius constitutum) such as Act Number 1/Pnps/1965, Act Number 1 Year 1974 on Marriage, and Act Number 39 of 1999 and future regulations (ius constituendum), such as the Draft's Religious Freedom Act. Third, explanation of Act Number 23 Year 2006 that ID card as one of the document of residence which is entrance for state recognition of citizen identity that are unique or unique, single and attached to a person as valid evidence for administrative and recording in accordance with the provisions of the law for the event of residence and important events for a person.

There is a clear rejection of the Constitutional Court Decision Number 97/PUUXIV/2016 which does not pay attention to the political agreement of the Indonesian establishment on the stream of belief in Decree of the People Consultative Assembly Number IV/MPR/1978 concerning about Outlines of the State which mentions Belief is

71 Indonesia's Constitutional Court Decision Number 97/PUU-XIV/2016, p. 153.

72 Ibid., p. 149-150.

73 Ibid., p. 150-151. 
not Religion. ${ }^{74}$ Political agreement is the substance of political life is an agreement on the fundamental things that bind all citizens into a political life. ${ }^{75}$ Consensus as John Locke puts it in contract theory that humans have various interests and aspirations of life, including personal protection that is impossible to convey aspirations individually. These humans form a society formed under a collective agreement. ${ }^{76}$ The consensus according to the constitution is based on three elements, among others. First, an agreement based on a shared goal embodied in Pancasila to achieve ideal goals in the life of a state. Second, the rule of law as the basis of government or state administration that the basis of government is the rule of law and the constitution. Third, forms of constitution and state administration procedures relating to state organs and procedures governing their power, relations between organs of the country to each other, and relationship between state organs and citizens. ${ }^{77}$

The earlier disenchanted political agreement was called the gentlement agreement on the 1945 Constitution as Soekarno, Soepomo and other founding fathers claimed that the gods were worshiped freely, not religious egoism, practiced religion in a civilized manner. An independent based on the God Almighty, mutual respect for each other (verdraagzaamheid ${ }^{78}$, and each class (among the largest religious and religious minorities) will unite with their state (zal zich thuis voelen). ${ }^{79}$ Each group is consciously and truly recognized have the privilege to be able to have national unity. Therefore, the existence of mutual respect for each other and recognize the differences in Indonesian society as a privilege not only in words or conversations or dialogues (communication) and speech but also through the real form (action) in the preparation of legislation. It is not enough to generate consensus in full, if not yet elaborate the theory proposed by Jürgen Habermas that the need for a balanced, equal and continuous dialogue between the state through the State Organizer and its citizens in maintaining the spirit of mutual commitment in overcoming that the problems. ${ }^{80}$ Skepticism only creates deadlock and sees everything as sensitive because of everything that is right and good will definitely create the right things and good also that is harmonization, brotherhood, appreciation, and respect for human dignity and prestige.

Related to the existence of invalid data about Believer and the difference that is very striking about data inventory Believer in all parts of Indonesia. According to data compiled by the Noble Assembly of Believing to God Almighty of Indonesia (MLKI) that the number of Believers believe there are about 12 million people and Directorate General of Culture predicts there are about 10-12 million Indigenous Belief's People.

74 Andi Nur Aminah (Red.).(2017). MUI Tegas Tolak Putusan MK Soal Penghayat Kepercayaan. Available from: http:/ / nasional.republika.co.id/berita/nasional/hukum/17/11/16/ozi8s3384-mui-tegas-tolakputusan-mk-soal-penghayat-kepercayaan. [Accessed January 29, 2017].

75 Efriza. (2016). Kekuasaan Politik: Perkembangan Konsep, Analisis dan Kritik. Malang: Instrans Publishing, p. 156.

76 Ibid.

77 Ibid., p. 158-160.

78 National Secretariat of Indonesia Republic. (1995). Risalah Sidang Penyelidik Usaha-usaha Persiapan Kemerdekaan Indonesia (BPUPKI) dan Panitia Persiapan Kemerdekaan Indonesia (PPKI). Jakarta: Ghalia Indonesia, p. 519.

79 Compilation Team of Comprehensive Manuscript of the Amendment of the 1945 Constitution of the State of the Republic of Indonesia. (2010). Naskah Komprehensif Perubahan Undang-Undang Dasar Negara Republik Indonesia Tahun 1945: Latar Belakang, Proses, dan Hasil Pembahasan 1999-2002, Buku VIII Warga Negara dan Penduduk, Hak Asasi Manusia dan Agama. Jakarta: Sekretaris Jenderal dan Kepaniteraan Mahkamah Konstitusi, p. 88-89.

80 F. Budi Hardiman. (2009). Demokrasi Deliberatif. Menimbang 'Negara Hukum' dan 'Ruang Publik' dalam Teori Diskursus Jürgen Habermas. Yogyakarta: Kanisius, p. 176. 
However, the data on the population of Indigenous Belief's People is different with the Census of Religion data in Indonesia from the Central Bureau of Statistics in 2010 that the followers of Islam as much as $87.18 \%$, Christian $6.96 \%$, Catholic $2.91 \%$, Hindu $1.96 \%$, Buddhist $0.72 \%$, Kong Hu Chu $0.05 \%$, and others $0.13 \%$ or less than 1 million people. Sri Hartini (Director of Belief of God Almighty at Education and Cultural Minister) explained that there are 187 organizations of Central Belief level in 13 provinces, while the regional level is 1,047 organizations spread over 27 provinces. ${ }^{81}$ According to the Author, first, the state can not provide maximum legal protection in all aspects of human life (important events in human life and constitutional rights) for Believer because state does not recognize well and accurately about existence and the number of Belief and Believer in all over Indonesia. Second, unrecognized data on the number of Believers is a discrimination in the administrative bureaucracy service for the Believers include taking care of ID cards, marriage records, birth certificates of children of Believers, burial places, and others. To fulfill the maximum protection, the state must recognize the existence of its citizens through its identity of knowing and knowing its citizens through official document of residence among them in the form of KTP.

Post Decision of the Constitutional Court, Jimly Asshiddiqie (Former Judges Constitutional Court) argues, Constitutional Court only decide or determine the principle that is discrimination for Believer on the basis an Act. It is not enough, because there are issues related to ID cards by government's administration with several possibilities. First, in the religious column it says strips (-) or slashes (/) [Religion/Belief]. Second, separate religious columns and individual confidence columns. Third, it finally comes to the conclusion that column of belief does not need to be listed at all as it is now most important that there is no discrimination. ${ }^{82}$ The main thing that people need is personal recognition as a whole and comprehensive both the identity and the basic rights inherent in the human being. The inclusion of columns or data elements of residence in the identity card includes name, place of birth date, sex, religion/belief, marital status, blood type, occupation address, nationality there shall be no discrimination (restriction, harassment, exclusion) and to know its citizens through accurate population data, and citizens must provide true information regarding the identity attached to it.

Based on the determination and statements to fight the independence and to eliminate the occupation through the Preamble of the 1945 Constitution in the integrity of pluralistic heterogeneous society culturally, politically, economically, and history. ${ }^{83}$ Indonesian is very sensitive for factors of breaking and destructive, the national sociopolitical policy must be alert as well as anticipatory and wise by fostering factors unite and constructive. Indonesia's government knows citizens appropriately through its inherent identity can fulfill its maximum obligations to citizens through equal, balanced, and parallel communication (dialogue) by removing any barrier attributes between parties and the process must also be sustainable. Compromise and negotiation of solutions to problems encountered through policy bargaining, willing to succumb, rationality and commitment to public. The result of the communication is not only in words but also manifested in the legislation to recognize the difference of society sincerely.

According to Habermas, the whole human action is based on and oriented on two things. First, orientation to the achievement of consensus or communicative action. Second,

81 MetroTv. Melawan Lupa:Keadilan Untuk Para Penghayat Kepercayaan. Watch on January 16, 2018.

82 Ibid.

83 M. Solly Lubis. (2014).Politik Hukum dan Kebijakan Publik (Legal Policy and Public Policy). Bandung: CV. Mandar Maju, p. 110-111. 
action-oriented rational action aims to meet the physical needs alone (instrumental action) and the orientation of human actions to influence others to achieve its goals (strategic action). 84 Communicative action to achieve mutual agreement or understanding between the parties who communicate, not based on domination and coercion of will ${ }^{85}$ through public participation.

The right man in the right position of the House of Representative in Republic of Indonesia has the burden of creating a democratic society that accommodates emancipatory community participation. Agree with Joseph Schumpeter, Maruto and Anwar argue that "Democracy is not just a system in which elites acquire the power to rule through a competitive struggle for the peoples vote." Democracy is not just about electing a leader or a member of parliament, but democracy is a political system that accommodates the needs of the community in a responsive manner. Therefore, the struggle effort and sacrifice of Believers of Faith individually or in groups through a single container that is MLKI is needed to fight for the right to recognition of existence and identity of Belief. For the future, when supported by the right person in the right position, it means people who are willing to genuinely acknowledge diversity and accommodate the needs of the community in a responsive manner. 86 Recognition plays an important role to always involve the public with an interest in the Act to be heard during the drafting of an act, when the act is being implemented. In the time of the amendment of the Adminduk Act through public participation as a reflection in the implementation of the act as a legal protection to put the whole community to position equivalent and parallel to release all attributes that rein in the form differences.

\section{Conclusion}

The issue of Religion and Belief in Indonesia as a very sensitive because of a narrow (exclusive) interpretation of "Belief in the God Almighty" and "and it's belief" in the legislation in every debate of the Organizer State causes the column of Belief not to be included in the ID card. Inclusion of the column's Belief as the recognition identity of a person who believes in God Almighty and mutual respect between human being without any discrimination. Implementation of Decision's Constitutional Court Number 97/PUU-XIV/2016 through the inclusion of the column's Belief on ID Card because the position of Believer and Follower of Religion are equal. Colomns on KTP are an access (entrance) for the acquisition of the right to important events in the life and civil right for Believer. Then, column or data element of population on KTP is personal recognition as a whole and comprehensive both identity and basic rights attached to the human being. In relation to legal protection in the inclusion of columns or elements of population data on KTP there shall be no discrimination (restriction, harassment, exclusion) have an obligation to know and know their citizens through accurate

84 Jurgen Habermas. (1982). The Theory Of Communicative Action: Reason And Rationalization Of Society. Boston: Beacon Press on Wimmy Haliim. (2016). "Demokrasi Deliberatif Indonesia: Konsep Partisipasi Masyarakat Dalam Membentuk Demokrasi dan Hukum Yang Responsif, Masyarakat Indonesia". Jurnal Masyarakat Indonesia, 42 (1): 23.

85 Wimmy Haliim. (2016). “Demokrasi Deliberatif Indonesia: Konsep Partisipasi Masyarakat Dalam Membentuk Demokrasi dan Hukum Yang Responsif, Masyarakat Indonesia". Jurnal Masyarakat Indonesia, 42 (1), June: 23.

86 M. D. Maruto and Anwar. (2002). Reformasi politik dan kekuatan masyarakat: Kendala dan Peluang Menuju Demokrasi. Jakarta: LP3ES, p. 32 on Wimmy Haliim. (2016). “Demokrasi Deliberatif Indonesia: Konsep Partisipasi Masyarakat Dalam Membentuk Demokrasi dan Hukum Yang Responsif, Masyarakat Indonesia", Jurnal Masyarakat Indonesia, 42 (1), Juni: 22. 
population data, and citizens must provide information in a manner pertinent to the identity. For the future, the national consensus's urgency and commitment of the government and its entire apparatus as universal about the right to recognition and diversity in the act. The inclusion of the column's Belief on ID card is important to be regulated that followed by a good inventory of the number of Belief and Believer annually. The most important is harmonizing legislation, so that legal products based on the 1945 Constitution to include the rule of public participation on regulation as a necessity that is parallel, balance, and sustainable between apparatus and society.

\section{References}

Aep Gunarsa, (Ed.) (2011). Butir-butir Pemikiran Dalam Hukum: Memperingati 70 Tahun Prof. Dr. B. Arief Sidharta, SH.. Bandung: PT. Refika Aditama.

Andi Nur Aminah (Red.). (2017). MUI Tegas Tolak Putusan MK Soal Penghayat Kepercayaan. Available from: http:/ / nasional.republika.co.id/berita/nasional/hukum/17/11/ 16/ozi8s3384-mui-tegas-tolak-putusan-mk-soal-penghayat-kepercayaan. [Accessed January 29, 2017].

Andy Yentriyani, etc. (2016). Laporan Hasil Pemantauan tentang Diskriminasi dan Kekerasan Terhadap Perempuan Dalam Konteks Kebebasan Beragama dan Berkeyakinan Bagi Kelompok Penghayat Kepercayaan/Penganut Agama Leluhur dan Pelaksana Ritual Adat. Jakarta: Komisi Nasional Anti Kekerasan Terhadap Perempuan.

Compilation Team of Comprehensive Manuscript of the Amendment of the 1945 Constitution of the State of the Republic of Indonesia. (2010). Naskah Komprehensif Perubahan Undang-Undang Dasar Negara Republik Indonesia Tahun 1945: Latar Belakang, Proses, dan Hasil Pembahasan 1999-2002, Buku VIII Warga Negara dan Penduduk, Hak Asasi Manusia dan Agama. Jakarta: Sekretaris Jendela dan Kepaniteraan Mahkamah Konstitusi Republik Indonesia.

Dewan Perwakilan Rakyat Republik Indonesia. (No Year). Proses Pembahasan Rancangan Undang-Undang Tentang Administrasi Kependudukan: Buku 1. Jakarta: Sekretariat Jenderal Dewan Perwakilan Rakyat Republik Indonesia.

(No Year). Proses Pembahasan Rancangan Undang-Undang Tentang Administrasi Kependudukan: Buku 2. Jakarta: Sekretariat Jenderal Dewan Perwakilan Rakyat Republik Indonesia.

Rancangan Undang-Undang Tentang Administrasi Kependudukan: Bu Sekretariat Jenderal Dewan Perwakilan Rakyat Republik Indonesia.

Dimas Dwi. (2017). Membandingkan e-KTP Ala Indonesia dengan MyKad Punya Malaysia. Available from: https://semarak.news/ 2017/03/14/11689-membandingkan-ektp-ala-indonesia-mykad-punya-malaysia.html.[Accessed October 9, 2017].

Efriza. (2016). Kekuasaan Politik: Perkembangan Konsep, Analisis dan Kritik. Malang: Instrans Publishing.

F. Budi Hardiman. (2009). Demokrasi Deliberatif. Menimbang 'Negara Hukum' dan 'Ruang Publik' dalam Teori Diskursus Jürgen Habermas. Yogyakarta: Kanisius. 
Fernando Randy. (2014). Ahok: Kolom Agama di KTP Tak Ada Gunanya. Available from: http:/ / politik.news.viva.co.id/news/read/514142-ahok--kolom-agama-di-ktptak-ada-gunanya. [Accessed September 4, 2014].

Foreign and Commonwealth Office. (2016). Freedom of Religion or Belief Toolkit: How the FCO can Help Promote and Protect This Human Right. Available from: https://www.gov.uk/government/uploads/system/uploads/attachment_data /file/561516/Freedom_of_Religion_or_Belief_Toolkit_-_2016.pdf.[Accessed January 23, 2017].

Husamah. (2009). “Mengusung Kembali Khazanah Identitas Budaya Bangsa”. Jurnal Bestari, 42: 36.

Ifdhal Kasim. (2000). "Konvensi Hak Sipil dan Politik, Sebuah Pengantar". Jurnal Analisis CSIS, XXIX(4): 413-416.

International Development Law Organization (IDLO). (No year).Freedom of Religion or Belief and The Law: Current Dillemas and Lessons Learned.New York: International Development Law Organization (IDLO).

Jeneman Pieter and John A. Titaley. (2014). "Hubungan Antar Agama dalam Kebhinekaan Indonesia (Studi Kasus Terhadap Hubungan Warga Jemaat GPIB Tamansari Pospel Kalimangli dengan Warga Muslim di Dusun Kalimangli)". Jurnal Waskita, 2(2): 20.

Jim Fussel. (2001). "Group Classification on National ID Cards as a Factor in Genocide and Ethnic Cleansing." Presented on November 15, 2001 to the Seminar Series of The Yale University Genocide Studies Program.

Mathews Thomas. (2004). “Is Malaysia's MyKad The 'One Card To Rule Them All' ? The Urgent Need To Develop A Proper Legal Framework For The Protection of Personal Information In Malaysia." Melbourne University Law Review, 28: 487.

M. Solly Lubis. (2014). Politik Hukum dan Kebijakan Publik (Legal Policy and Public Policy). Bandung: CV. Mandar Maju.

Mukti Fajar ND and Yulianto Achmad. (2007). Buku Ajar: Dualisme Penelitian Hukum. Yogyakarta: Pensil Komunika.

National Secretariat of Indonesia Republic. (1995). Risalah Sidang Penyelidik Usaha-usaha Persiapan Kemerdekaan Indonesia (BPUPKI) dan Panitia Persiapan Kemerdekaan Indonesia (PPKI). Jakarta: Ghalia Indonesia.

Parluhutan Siregar. (2014). "Etika Politik Global: Isu Hak-hak Asasi Manusia”. Jurnal Penelitian Medan Agama, 6(1): 11.

Peter Mahmud Marzuki. (2005).Penelitian Hukum. Surabaya: Kencana.

PSA. Recognising Recognition: Hannah Arendt on (the Right to Have) Rights. Available from: https://www.psa.ac.uk/sites/default/files/ 988_509.pdf. [Accessed January 16, 2018].

Rahmat Subagya. (1990). Kepercayaan, Kebatinan, Kerohanian, Kejiwaan, dan Agama. Yogyakarta: Kanisius.

Randy Ferdi Firdaus. (2013). Ketua MPR: Syiah, Sunni, Ahmadiyah Saya Terima di Sini. Available from: http://m.merdeka.com/peristiwa/ketua-mpr-syiah-sunniahmadiyah-saya-terima-di-sini.html. [Accesed December, 21 20018]. 
Rudy Gunawan. (2013). “Pembelajaran Nilai-nilai Pahlawan Kemerdekaan Soekarno Dalam Rangka Mengembalikan Karakter Bangsa Indonesia."Journal Widya, 1(1), July-December: 5.

Sekretariat Kerjasama Kepercayaan (Kebatinan, Kejiwaan, dan Kerohanian) Pusat.(1972). Buku Kenang-kenangan Symposium Nasional Kepercayaan (Kebatinan, Kejiwaan, dan Kerohanian).Jakarta: Komisi Kodifikasi Sekretariat Kerjasama Kepercayaan (Kebatinan, Kejiwaan, dan Kerohanian) Pusat.

Sudarsono. (2007). Kamus Hukum Edisi Baru. Jakarta: Rineka Cipta.

Theo Huijbers. (2006). Filsafat Hukum Dalam Lintasan Sejarah. Yogyakarta: Pustaka Filsafat.

Trisno S. Susanto, dkk. (2011). Kertas Posisi: Menuntut Pemenuhan Hak-hak Konstitusional Penghayat Kepercayaan Terhadap Tuhan Yang Maha Esa. Jakarta: Human Rights Working Group.

Universitas Mercu Buana. Modul Perkuliahan Pendidikan Kewarganegaraan Pokok Bahasan Identitas Nasional. Available from: http://studylibid.com/doc/27027/a.pengertian-identitas-nasional. [Accessed January 8, 2018].

Wimmy Haliim. (2016). "Demokrasi Deliberatif Indonesia: Konsep Partisipasi Masyarakat Dalam Membentuk Demokrasi dan Hukum Yang Responsif, Masyarakat Indonesia". Jurnal Masyarakat Indonesia, 42(1), Juni: 22.

Yusdani. (2011). "Kebebasan Beragama Perspektif Hak Asasi Manusia". Al-Mawarid, XI(2), September-January: 273. 